\title{
Benign persistent papular acantholytic and dyskeratotic eruption: a case report and review of the literature
}

\author{
TH.VAN JOOST, V.D.VUZEVSKI,* B.TANK AND H.E.MENKE† \\ Departments of Dermato-Venereology and ${ }^{*}$ Clinical Pathology. Erasmus University. Rotterdam \\ †Department of Dermatology. St Franciscus Hospital, Rotterdam. The Netherlands \\ Accepted for publication 16 July 1990
}

\begin{abstract}
Summary We report a case of a 35-year-old female with a persistent pruritic acantholytic and dyskeratotic eruption on the chest and vulva. The light and electron microscopic studies showed suprabasal epidermal clefting with acantholysis and dyskeratotic cells. We suggest that the most appropriate term for this case is that of benign persistent papular acantholytic and dyskeratotic eruption.
\end{abstract}

Several different papular or papulo-vesicular conditions with acantholysis and accompanied by various degrees of dyskeratosis have been described. ${ }^{1-10}$ Except for the condition of transient acantholytic dermatosis (Grover's disease), ${ }^{4}$ all the other dermatoses usually followed a more or less chronic course (Table 1).

There have been several reports of a papular eruption with acantholysis and dyskeratosis that is restricted to the vulvocrural areas ${ }^{10.11-17}$ (Table 2). These cases have been described as atypical vulval Hailey-Hailey disease $\mathrm{e}^{11-14}$ or vulval warty dyskeratosis. ${ }^{15}$ We report a patient with a persistent papular acantholytic and dyskeratotic eruption that involved the submammary areas and the vulva.

\section{Case report}

A 35-year-old female patient had a persistent history, of more than 3 years, of discrete and partly symmetrical papular lesions in the submammary region and, at the same time, more itchy and painful papules on the inner aspect of the labia majora. There was no family history of similar eruptions. The vulval lesions were clearly defined, flesh-coloured, partly grouped papules that measured 3-5 mm in diameter and some of them were eroded (Fig. 1). There were slightly keratotic discrete, light-brown skin lesions in the submammary region that clinically resembled Grover's disease. The more painful vulval lesions were excised. There were no lesions in the perianal region or in the mouth. Swabs taken from the patient and her sexual partner showed no evidence of Candida infections.

\section{Histology}

Light microscopy studies of biopsies from the submammary regions showed marked acantholysis and minimal

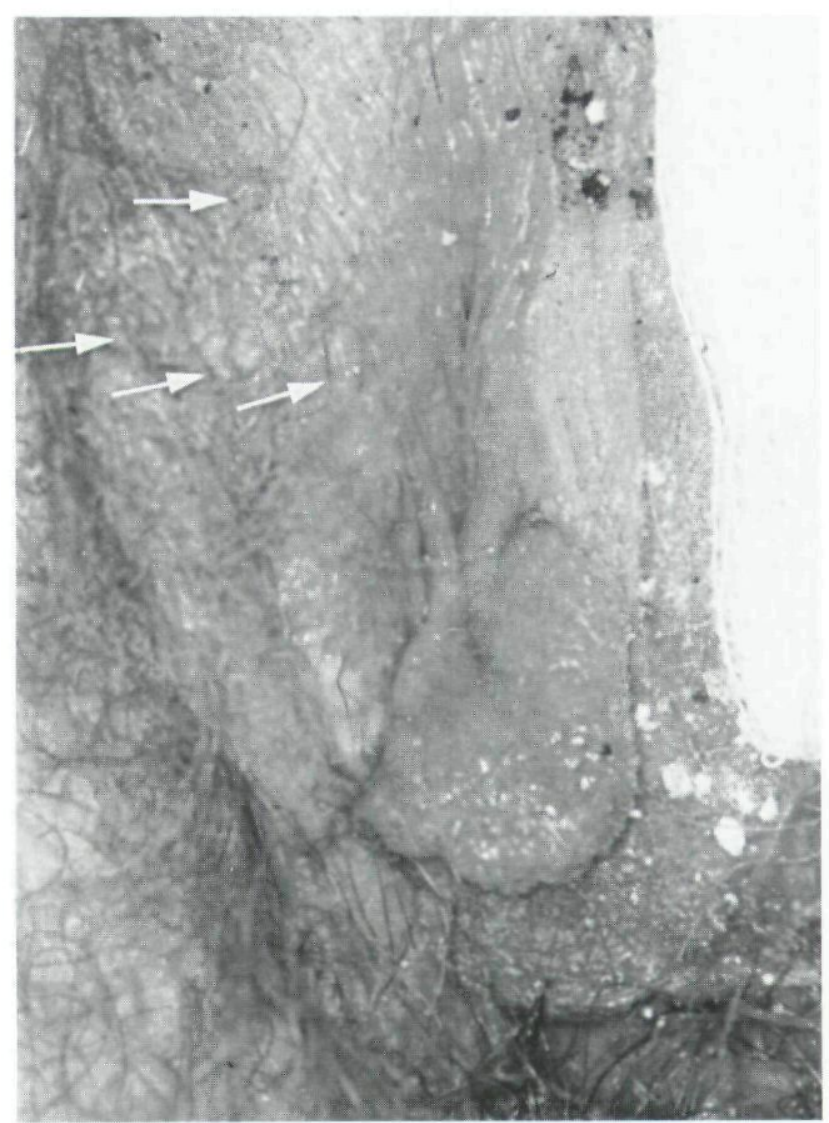

Figure 1. Grouped and solitary flesh-coloured papules on the right labium (arrows). 
Table 1. Acantholytic eruptions with combined variations in dyskeratosis

\begin{tabular}{|c|c|c|c|c|}
\hline Reference & Classification & Hereditary & Duration & $\begin{array}{l}\text { Dyskeratosis } \\
\text { (usual pattern) }\end{array}$ \\
\hline 1 & Darier's disease & + & Persistent & Marked \\
\hline 2 & $\begin{array}{l}\text { Acantholytic dyskeratotic } \\
\text { (zosteriform) naevus } \\
\text { (Darier's disease?) }\end{array}$ & - & Persistent & Marked \\
\hline 3 & Warty dyskeratosis & - & Persistent & Marked \\
\hline 4 & $\begin{array}{l}\text { Grover's disease (transient } \\
\text { acantholytic dermatosis) }\end{array}$ & - & Transient & $\begin{array}{l}\text { Moderate, } \\
\text { Minimal or lacking }\end{array}$ \\
\hline 5 & Hailey-Hailey disease & + & Persistent & Minimal \\
\hline 6 & $\begin{array}{l}\text { Acantholytic squamous cell } \\
\text { carcinoma }\end{array}$ & - & Persistent & Minimal \\
\hline 7 & $\begin{array}{l}\text { Persistent acantholytic } \\
\text { dermatosis* }\end{array}$ & - & Persistent & Moderate \\
\hline 8 & $\begin{array}{l}\text { Persistent acantholytic } \\
\text { dermatosis related to } \\
\text { actinic damage* }\end{array}$ & - & Persistent & Moderate or marked \\
\hline 9 & $\begin{array}{l}\text { Benign papular acantholytic } \\
\text { dermatosis (BPAD)* }\end{array}$ & - & Persistent & Minimal or lacking \\
\hline 10 & $\begin{array}{l}\text { Acantholytic dermatosis* } \\
\text { localized to the vulvocrural area }\end{array}$ & - & Persistent & Minimal or moderate \\
\hline
\end{tabular}

* Descriptive (provisional) diagnosis.
Table 2. Acantholytic and dyskeratotic lesions of the vulvocrural region

\begin{tabular}{|c|c|c|c|c|c|}
\hline Reference & $\begin{array}{c}\text { Number of } \\
\text { cases }\end{array}$ & $\begin{array}{c}\text { Age } \\
\text { (years) }\end{array}$ & $\begin{array}{l}\text { Provisional } \\
\text { classification }\end{array}$ & $\begin{array}{l}\text { Duration } \\
\text { (months) }\end{array}$ & $\begin{array}{l}\text { Other } \\
\text { location }\end{array}$ \\
\hline 10 & 6 & $28,37,47,53,63,83$ & $\begin{array}{l}\text { (Distinct syndrome?) } \\
\text { Acantholytic } \\
\text { dermatosis of the } \\
\text { vulvocrural area }\end{array}$ & $12-36$ & No \\
\hline 11 & 1 & 22 & Hailey-Hailey disease & 12 & No \\
\hline 12 & 1 & 29 & Hailey-Hailey disease & 7 & No \\
\hline 13 & 1 & 39 & Hailey-Hailey disease & 12 & No \\
\hline 14 & 1 & 38 & Hailey-Hailey disease & $?$ & No \\
\hline 15 & 3 & $49,38,52$ & Warty dyskeratosis & $6-24$ & No \\
\hline 16 & 1 & 29 & $\begin{array}{l}\text { Papular acantholytic } \\
\text { dyskeratosis of the } \\
\text { vulva (Hailey-Hailey or } \\
\text { Grover's disease or } \\
\text { distinct syndrome?) }\end{array}$ & 72 & No \\
\hline 17 & 1 & 47 & $\begin{array}{l}\text { Papular acantholytic } \\
\text { dyskeratosis }\end{array}$ & 36 & No \\
\hline Present case & 1 & 35 & $\begin{array}{l}\text { (Distinct syndrome?) } \\
\text { Benign persistent } \\
\text { papular acantholytic } \\
\text { dyskeratotic eruption }\end{array}$ & 36 & Yes \\
\hline
\end{tabular}

dyskeratosis. Histology of the labia majora lesions showed a suprabasal epidermal cleft with typical acantholytic cells. Above the split, within the epidermis, there were dyskeratotic cells (Fig. 2). Small villous-like bodies were observed consisting of dermal papillae covered with a single layer of cuboidal cells with pyknotic nuclei that projected into the cleft. There were a number of inflammatory cells surrounding the cleft. 


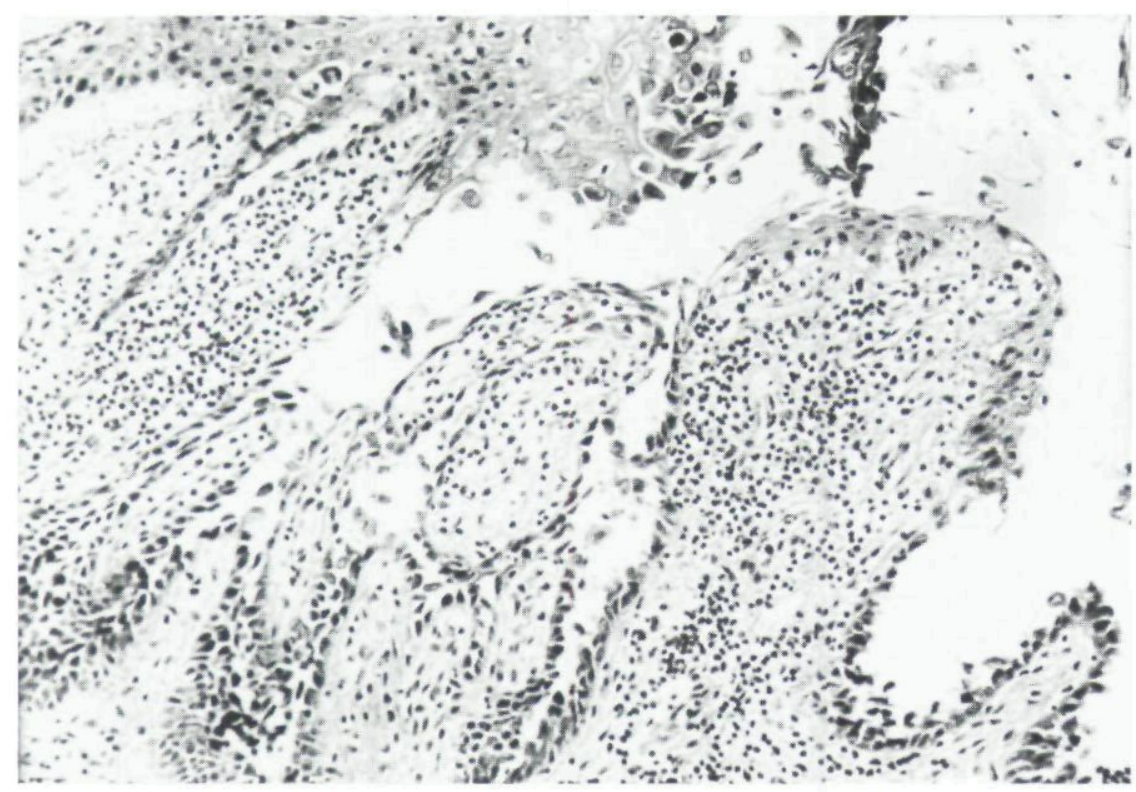

Figure 2. Histology of a papular lesion on the vulva showing suprabasal acantholysis and to a lesser extent dyskeratosis of the upper epidermis (haematoxylin and eosin, $\times 216$ ).

\section{Immunofluorescence}

Direct immunofluorescence was negative with no deposition of immunoglobulins or complement in the skin.

\section{Electron microscopy}

This was performed only on the vulval lesions and the ultrastructural changes were those of acantholysis and dyskeratosis. There was a total disappearance of intercellular connections and the number of desmosomes appeared to be reduced. The tonofilaments were detached from the desmosomal plate, often aggregated around the nucleus. The tonofilament aggregations were dense, wavy and band-like and were mostly observed in the cells of the Malphigian layer, but also in isolated cells within the cleft (Fig. 3).

\section{Cytokeratin studies}

These were carried out on the vulval lesions using commercially available monoclonal antibodies and using methods described previously ${ }^{18}$. Staining for antipolykeratin was observed but there was no staining for anticytokeratin 7 (RRCK 105), anticytokeratin 18 and 19 (5D3). RKSE 60 (anticytokeratin 10) detects suprabasal cytokeratin filaments, ${ }^{19}$ but was absent in the vulval lesions in our patient.

\section{Discussion}

In 1972 Ackerman ${ }^{6}$ introduced the term 'focal acantho-

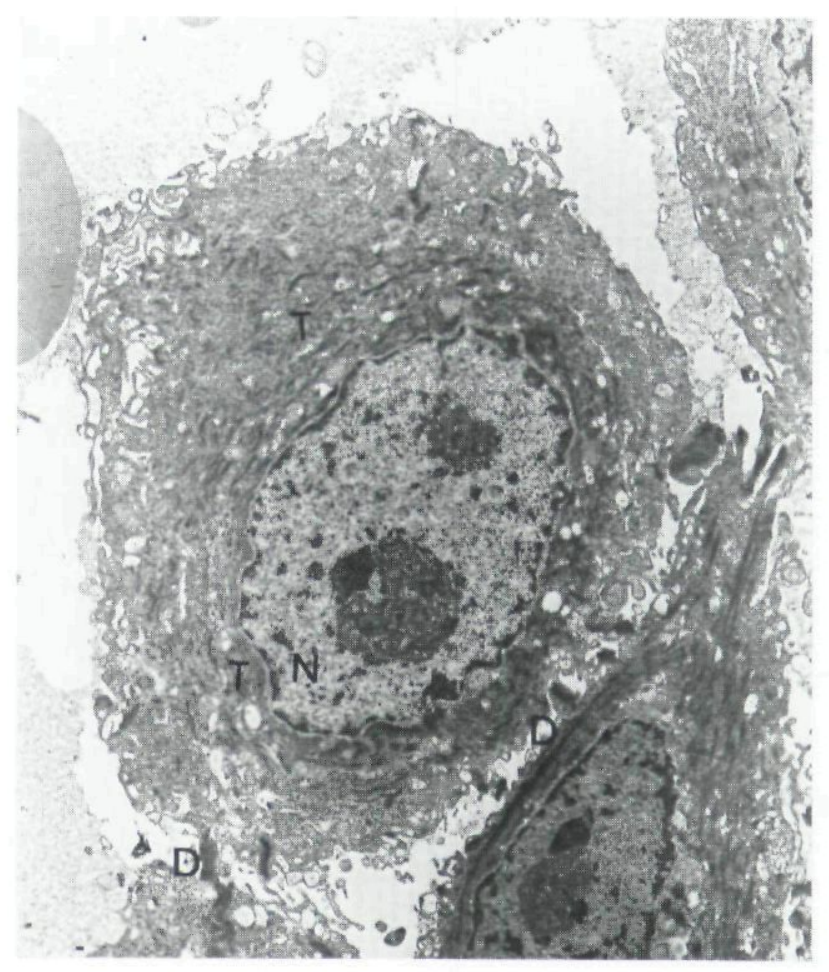

Figure 3. Electron micrograph of a vulval lesion. This shows acantholytic cells, tonofilaments (T) detached from the desmosomal plate (D) and aggregated around the nucleus $(\mathrm{N}) . \times 5200$.

lytic dyskeratosis' for clinical and histopathological conditions other than typical Darier's disease. A case was reported ${ }^{16}$ of a papular acantholytic and dyskeratotic dermatosis of the vulva and it was questioned as to 
whether this may be a distinct entity. Coppola et al. ${ }^{17}$ reported a patient with vulval and perineal papular lesions that coalesced to form plaques and this case was described as being 'papular acantholytic dyskeratosis'. Six patients were later reported with an acantholytic dermatosis localized to the vulvocrural area. ${ }^{10}$ The histology in these cases showed acantholytic dyskeratosis that resembled Darier's disease or when there was minimal dyskeratosis. Hailey-Hailey disease (Tables 1 and 2). The presence of Candida in some of these cases could explain the apparent location of the vulval lesions. None of these patients had a family history and none had similar lesions elsewhere on the body as was observed in our case.

In Grover's disease and in the syndrome of benign papular acantholytic dermatosis described by Heaphy et al., ${ }^{9}$ in which lesions occurred on the trunk and the neck, dyskeratosis can be minimal or absent. The histology of the submammary lesions in our case resembled that seen in Grover's disease or that described by Heaphy et al. ${ }^{9}$ The vulval lesions in our case ultrastructurally resembled the pattern described for transient Grover's disease. ${ }^{20.21}$ The combination of the clinical features, persistent nature and absence of family history with the histopathology of the submammary lesions, however, resemble more closely that of the acantholytic and dyskeratotic type of benign papular acantholytic dermatosis. Our patient had not only vulval but also submammary lesions. A further finding of interest in our case was that staining with antipolykeratin monoclonal antibody was observed, but that cytokeratin 10 was absent.

Although this is a report of a single case, we conclude from the clinical and histopathological findings that our patient is best classified as having a benign persistent papular acantholytic and dyskeratotic eruption.

\section{References}

1 Gottlieb SK, Lutzner MA. Darier's disease. Arch Dermatol 1973; 107: 225-30.
2 Starink TM, Woerdeman MJ. Unilateral systematized keratosis follicularis. A variant of Darier's disease or an epidermal naevus (acantholytic dyskeratotic epidermal naevus?) Br J Dermatol 1981: 105: 207-14.

3 Gorlin RJ, Peterson WC. Warty dyskeratoma. Arch Dermatol 1967; 95: 292-3.

4 Grover RW. Transient acantholytic dermatosis. Arch Dermatol 1970: 101: 426-34.

5 Hailey H. Hailey H. Familial benign chronic pemphigus. Arch Dermatol 1939: 39: 679-85.

6 Ackerman AB. Focal acantholytic dyskeratosis. Arch Dermatol 1972; 106: 702-6.

7 Simon RS, Bloom D. Ackerman AB. Persistent acantholytic dermatosis. Arch Dermatol 1976; 112: 1429-31.

8 Fawcett HA. Miller JA. Persistent acantholytic dermatosis related to actinic damage. Br J Dermatol 1983; 109: 349-54.

9 Heaphy MR. Tucker SB, Winkelmann RK. Benign papular acantholytic dermatosis. Arch Dermatol 1976; 112: 814-21.

10 Cooper PH. Acantholytic dermatosis localized to the vulvocrural area. J Cutan Path 1989; 16: 81-4.

11 Lyles TW, Knox JM, Richardson JB. Atypical features in familial benign chronic pemphigus. Arch Dermatol 1958: 78: 446-53.

12 Hazelrigg DE. Stoller LJ. Isolated familial benign chronic pemphigus. Arch Dermatol 1977: 113: 1302.

13 King DT, Hirose FM, King LA. Simultaneous occurrence of familial benign chronic pemphigus (Hailey's-Hailey's disease) and syringoma of the vulva. Arch Dermatol 1978: 114: 801.

14 Evron S, Leviatan A, Okon E. Familial benign chronic pemphigus appearing as leukoplakia of the vulva. Int J Dermatol 1984: 23: 556-557.

15 Duray PH. Merino MJ. Asiotis G. Warty dyskeratosis of the vulva. Int J Gynecol Pathol 1983: 2: 286.

16 Chorzelski TP, Kudejko J. Jablonska S. Is papular acantholytic dyskeratosis of the vulva a new entity? Am J Dermatopathol 1984: 6: $557-9$

17 Coppola G, Muscardin LM. Piazza P. Papular acantholytic dyskeratosis. Am / Dermatopathol 1986: 8: 364-6.

18 Habets JMW. Tank B. Vuzevski VD et al. Absence of Cytokeratin 8 and inconsistent expression of cytokeratins 7 and 19 in human basal cell carcinoma. Anticancer Research 1988: 8: 611-16.

19 Leigh IM, Pulford KA, Ramaekers FCS, Lane EB. Psoriasis: maintenance of an intact monolayer basal cell differentiation compartiment in spite of proliferation. Br J Dermatol 1985; 113: 53-64.

20 Kanzaki T, Hashimoto K. Transient acantholytic dermatosis of oral mucosa. J Cutan Pathol 1978: 5: 23-30.

21 Grover RW, Duffy LW. Transient acantholytic dermatosis: Electron microscopic study of the Darier type. J Cutan Pathol 1975; 2: 11127. 
This document is a scanned copy of a printed document. No warranty is given about the accuracy of the copy. Users should refer to the original published version of the material. 